\title{
Release of Protoplasts from Schizophyllum commune by a Lytic Enzyme Preparation from Trichoderma viride
}

\author{
By O. M. H. DE VRIES AND J. G. H. WESSELS \\ Department of Botany, University of Groningen, Haren, The Netherlands
}

(Received 2 February 1972; revised 28 April 1972)

\begin{abstract}
SUMMARY
Spherical, osmotically sensitive protoplasts were liberated from the mycelium of Schizophyllum commune through the action of an extracellular enzyme preparation from the culture filtrate of Trichoderma viride grown on hyphal walls of the former organism. The conditions for obtaining stable protoplasts were determined. Maximum numbers of protoplasts were released from young growing mycelium by using $\mathrm{MgSO}_{4}$ or $\mathrm{KCl}$ at an osmotic potential between $-\mathrm{I} 2.8$ and -17.8 atm in the presence of $0.05 \mathrm{M}$-maleic acid- $\mathrm{NaOH}$ at $\mathrm{pH} 5.8$. Protoplasts were released through ruptures in the wall, initially at the apices, but later also from older parts of the hyphae.
\end{abstract}

\section{INTRODUCTION}

There are a number of studies on the liberation of protoplasts from filamentous fungi (reviewed by Strunk, 1970). The organisms described represent all the major groups of fungi, but only one study concerns a basidiomycete (Polystictus versicolor) (Strunk, I969). In general, quantitative data were not given on the optimal conditions for the liberation of protoplasts.

Schizophyllum commune has been used extensively for studies on differentiation and morphogenesis (Niederpruem \& Wessels, I969; Wessels, I97I) and for this reason we investigated the conditions which favour a reproducible and efficient release of protoplasts from the hyphae of this basidiomycete. The availability of protoplasts may be very useful for further morphological, biochemical and genetic studies with this organism. We report here the effective use of an enzyme preparation derived from Trichoderma viride for the release of protoplasts from the hyphae of $S$. commune.

\section{METHODS}

Organisms. The strains of Schizophyllum commune used were the homokaryotic strain 699 obtained from Dr J. R. Raper (Harvard University, Cambridge, Massachusetts, U.S.A.) and a dikaryotic strain $\mathrm{K} 8$ derived from the KNIEP stock (Wessels, I965). Trichoderma viride (CBS 354.33) was obtained from the Centraalbureau voor Schimmelcultures, Baarn, The Netherlands.

Lytic enzymes. To obtain enzymes lytic towards walls of Schizophyllum commune, Trichoderma viride was grown in a liquid medium containing glucose $(0 \cdot 3 \%), S$. commune hyphal walls $(0.5 \%)$ and mineral components (Mandels, Parrish \& Reese, I962). The cultures were incubated for 8 days at $25^{\circ} \mathrm{C}$ on a New Brunswick gyratory shaker (225 rev./min). Hyphal walls were prepared from the mycelium of $S$. commune stock $\mathrm{K} 8$ grown in shaken cultures 
of minimal medium (Wessels, 1965) for 3 to 4 days at $25^{\circ} \mathrm{C}$. This stock was chosen because it does not produce slime, thus facilitating cleaning of the walls.

Lytic enzymes were precipitated from the Trichoderma viride culture filtrate by adding ammonium sulphate to $75 \%$ saturation (Hasegawa \& Nordin, 1969). The precipitate was taken up in water and, after dialysis against water, insoluble material was removed by centrifugation. The enzyme solution was then lyophilized and stored desiccated at $-20^{\circ} \mathrm{C}$. The lyophilized enzyme preparation maintained its ability to release protoplasts for at least I year. The protein content varied from 25 to $80 \%$ of the dry weight, depending on the preparation. The average yield amounted to about $100 \mathrm{mg}$ of soluble protein/l culture filtrate. The snail digestive juices used were Helicase (Industrie Biologique Française, Seine, France) and Glusulase (Endo Laboratories New York, USA).

Enzymatic and chemical assays. Hydrolytic activities on substrates were measured by incubating enzyme solution $(0.5 \mathrm{ml})$ at a suitable concentration with substrate $(0.5 \mathrm{ml})$ in $0.05 \mathrm{M}$-Sörensen phosphate buffer $(\mathrm{pH} 6.2)$ at $30{ }^{\circ} \mathrm{C}$. Substrates - final concentrations and times of incubation were: laminarin $(\beta-1,3$-glucan, Koch-Light Laboratories, Colnbrook, Buckinghamshire) $0.1 \%, 30 \mathrm{~min}$; pustulan $(\beta$-I,6-glucan, gift of Dr E. T. Reese, U.S. Army Natick Laboratory, Natick, Massachusetts, U.S.A.), $0.05 \%, 2 \mathrm{~h}$; nigeran ( $\alpha$-I, $3, \alpha$-I, 4 -glucan, Koch-Light Laboratories), 0.I \%, I h; starch ( $\alpha$-I,4-glucan), 0.I \%, $30 \mathrm{~min}$; cellulose ( $\beta$-I,4-glucan, Whatman, Balston Ltd, Maidstone, Kent), $0 \cdot 2 \%, \mathrm{I}$ h; chitin $(\beta$-I,4-linked $N$-acetyl-glucosamine, Fluka, Buchs, Swizerland), $0.2 \%, 2 \mathrm{~h}$; R-glucan $(\beta$-1,3, $\beta$-1, 6 -glucan $)$, $0.2 \%, 2 \mathrm{~h}$; S-glucan ( $\alpha$-I,3-glucan), $0.2 \%, \mathrm{I}$ h. Cellulose and chitin were used in an acidswollen state and were prepared according to Walseth (1963) and Skujins, Potgieter \& Alexander (1965) respectively. R- and S-glucan were prepared from hyphal walls of Schizophyllum commune K.35 dikaryon as described by Wessels (1965) except that the Rglucan was not treated with hot alkali. Chitinase activity was measured in mixtures supplemented with Io $\mu \mathrm{g} \beta$-glucosidase (Sigma Chemical Co., St. Louis, Missouri, U.S.A.). The reactions were stopped by the addition of I $\mathrm{ml} \mathrm{o} \cdot \mathrm{I}_{5} \mathrm{M}-\mathrm{Ba}(\mathrm{OH})_{2}$ followed by I $\mathrm{ml} \mathrm{ZnSO}_{4}$ $(5 \%, \mathrm{w} / \mathrm{v})$ and the mixtures were centrifuged at $2000 \mathrm{~g}$ for io min. Products released from insoluble glucans were measured with the anthrone reagent (Fairbairn, I953), those released from soluble glucans with the neocuproine reagent (Dygerts, Li, Florida \& Thoma, 1965) and $N$-acetylglucosamine released from chitin with the 4-dimethylaminobenzaldehyde reagent (Reissig, Strominger \& Leloir, 1955). Enzyme activities are expressed as mg glucose or $N$-acetylglucosamine equivalents liberated/mg protein.

Protein was determined by the method of Lowry, Rosebrough, Farr \& Randall (I95I) with bovine albumin (Sigma) as a standard.

Preparation of mycelium for protoplast release. Schizophyllum commune strain 699 was grown in minimal medium (Wessels, 1965). Erlenmeyer flasks were inoculated with a mycelial suspension of a culture grown on malt agar fragmented in minimal medium in a Waring blender at full speed $(2 \mathrm{~min})$; cultures were incubated at $25^{\circ} \mathrm{C}$ on a gyratory shaker (225 rev./min). Mycelium was collected on nylon cloth, washed several times with water, followed by two washings with ice-cold $0.05 \mathrm{M}$-maleic acid-NaOH buffer (pH 5.8). After elimination of a few larger pieces of mycelium a fairly homogeneous suspension was obtained. The mycelium was finally washed twice with a solution that contained an osmotic stabilizer and $0.05 \mathrm{M}$-maleic acid adjusted together to $\mathrm{pH} 5.8$ with $\mathrm{NaOH}$. Osmotic potentials were measured cryoscopically (Advanced Instruments, Newton Highlands, Massachusetts, U.S.A.).

Counting of protoplasts. After incubation of mycelium with lytic enzyme preparations in closed tubes at $25^{\circ} \mathrm{C}$, samples were counted for protoplasts in a haemocytometer. The mean 
Table I. Activities* in lytic enzyme preparations on several polysaccharides

$\begin{array}{lccc}\text { Substrates } & \begin{array}{c}\text { Trichoderma } \\ \text { enzyme } \\ \text { preparation }\end{array} & \text { Helicase } & \text { Glusulase } \\ \text { Chitin } & \mathbf{I} \cdot 76 & 0.19 & 0.08 \\ \text { R-glucan } & 28.60 & 0.65 & 0.44 \\ \text { Laminarin } & 20.60 & 2.80 & 2.74 \\ \text { Pustulan } & 0.95 & 0.60 & 0.33 \\ \text { S-glucan } & 2.77 & 0.00 & 0.00 \\ \text { Nigeran } & 0.09 & 0.00 & 0.00 \\ \text { Cellulose } & 0.00 & 1.63 & 0.63 \\ \text { Starch } & 7.88 & 0.20 & 0.26\end{array}$

* mg glucose or $N$-acetylglucosamine equivalents liberated/mg protein. For conditions see text.

number of protoplasts per $0.004 \mu \mathrm{l}$ was determined for 5 to Io grid areas. In some cases micro-chambers were used as described by Bartnicki-Garcia \& Lippman (1966). One drop of a washed mycelial suspension was placed in the chamber. Adherent fluid was removed with a capillary pipette and the components of the final incubation mixture (total volume $50 \mu 1$ ) were added. Incubation was at room temperature. The mean number of protoplasts from 5 to Io objective fields was determined by using either a $\times 20$ or $\times 40$ objective lens. The release of protoplasts was followed with a phase-contrast microscope (Wild M 20) and photographs were taken by using electronic flash.

\section{RESULTS}

\section{Hydrolytic activities of various enzyme preparations}

Some of the enzyme activities of the Trichoderma viride enzyme system and of two different preparations of snail digestive juice were compared (Table I). The snail-enzyme preparations were very similar, without any activity towards S-glucan. In contrast, the $T$. viride enzyme preparation was capable of degrading this glucan but did not display any cellulase activity. Only the $T$. viride lytic enzyme system which was able to degrade the wall components chitin, R-glucan and S-glucan induced protoplast liberation in Schizophyllum commune. The snail-enzyme preparations failed to do so even at concentrations up to $75 \mathrm{mg}$ protein $/ \mathrm{ml}$. The $T$. viride enzyme preparations never completely digested the hyphae. Even after 5 days of incubation remnants of hyphae remained visible, although the walls appeared much thinner and septa had completely disappeared.

\section{Choice of buffer and $p H$}

Na-maleate buffer and Sörensen phosphate buffer, both at $0.05 \mathrm{M}$, were satisfactory for release of protoplasts. In general, protoplasts could be obtained at $\mathrm{pH}$ values between 4.9 and 6.2 , provided an osmotic stabilizer was present. $\mathrm{MgSO}_{4}(0.5 \mathrm{M})$ was very effective in this respect. Since $\mathrm{MgSO}_{4}$ is not compatible with Sörensen buffer in the effective $\mathrm{pH}$ range, the optimal $\mathrm{pH}$ for protoplast release was determined in solutions containing $0.05 \mathrm{M}$-maleic acid and $0.5 \mathrm{M}-\mathrm{MgSO}_{4}$ adjusted with $\mathrm{NaOH}$ to $\mathrm{pH}$ values ranging from 5.2 to 6.6 (Fig. I). The maximum number of protoplasts was observed around $\mathrm{pH} 5 \cdot 8$.

\section{Effect of culture age}

Fig. 2 shows that the age of the mycelium strongly affected the yield of protoplasts, which was greatly reduced when the mycelium had been grown for more than 3 days. 


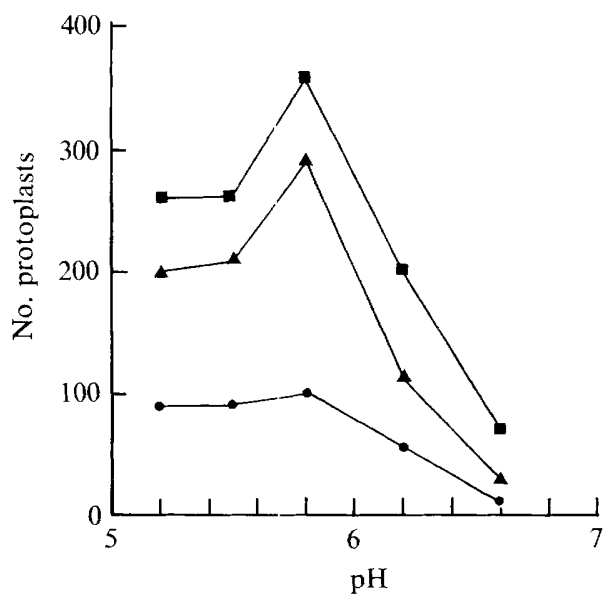

Fig. I

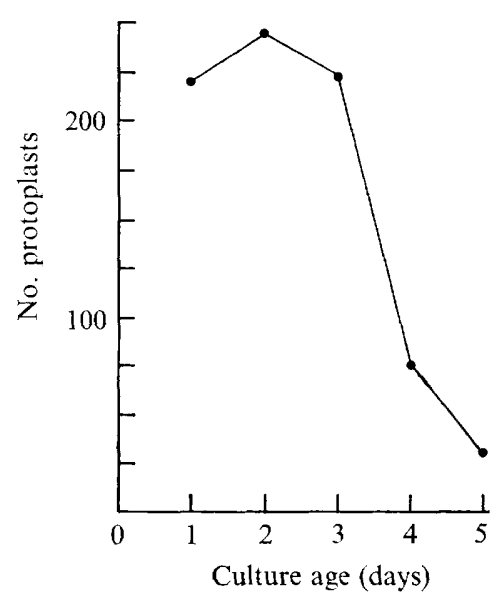

Fig. 2

Fig. I. Influence of $\mathrm{pH}$ on the production of protoplasts. Solutions containing $0.05 \mathrm{M}$-maleic acid and $0.5 \mathrm{M}_{-} \mathrm{MgSO}_{4}$ were adjusted to the desired $\mathrm{pH}$ with $\mathrm{NaOH}$. Mycelial age 2 days. Concentration of Trichoderma enzymes, $0.6 \mathrm{mg}$ protein $/ \mathrm{ml}$. Incubations were done in micro-chambers. Protoplasts were counted after: $0,3 \mathrm{~h} ; \boldsymbol{\Lambda}, 4 \mathrm{~h} ; \boldsymbol{\Pi}, 5 \mathrm{~h}$.

Fig. 2. Influence of culture age on the liberation of protoplasts. Concentrations were: Trichoderma enzymes, $2.5 \mathrm{mg}$ protein $/ \mathrm{ml}$; Na-maleate buffer, $0.05 \mathrm{M}$; $\mathrm{MgSO}_{4}, 0.5 \mathrm{M}$. Final $\mathrm{pH} 5.8$. Incubations were done in micro-chambers. Protoplasts were counted after $5 \mathrm{~h}$.

\section{Effect of $\mathrm{MgSO}_{4}$ concentration}

Solutions of varying osmotic potential were prepared using different concentrations of $\mathrm{MgSO}_{4}$ in $0.05 \mathrm{M}$-maleic acid adjusted to a final $\mathrm{pH}$ of 5.8 with $\mathrm{NaOH}$. Above $0.8 \mathrm{M}-\mathrm{MgSO}_{4}$ a linear relationship between the concentration of $\mathrm{MgSO}_{4}$ and the osmotic potential of the solution no longer existed. This was because additional $\mathrm{NaOH}$ was needed to counteract a decrease in $\mathrm{pH}$ due to $\mathrm{MgSO}_{4}$. Fig. 3 shows the formation of protoplasts in these solutions. In buffer alone $(\psi=-2.66 \mathrm{~atm})$ no protoplasts were released. At $0 . \mathrm{I} \mathrm{M}-\mathrm{MgSO}_{4}$ the protoplasts disintegrated soon after their appearance and after $4 \mathrm{~h}$ of incubation they could no longer be detected. The initial rate of protoplast liberation was highest at $0 \cdot 2 \mathrm{M}-\mathrm{MgSO}_{4}$ but the protoplasts were unstable. Increasing the molarity of $\mathrm{MgSO}_{4}$ caused a decrease in the rate of protoplast release. However, between 0.4 and $0.6 \mathrm{M}-\mathrm{MgSO}_{4}$ the maximal number of protoplasts was liberated. After $8 \mathrm{~h}$ virtually no new protoplasts arose and the total number remained stationary for at least $\mathrm{I} 6 \mathrm{~h}$. Increasing the osmolarity beyond $0.6 \mathrm{M}-\mathrm{MgSO}_{4}$ decreased the stability of the protoplasts. At a very high concentration of $\mathrm{MgSO}_{4}(\mathrm{I} \cdot 5 \mathrm{M})$ the hyphae became completely plasmolysed and the cytoplasm was divided into small spheres which were not released from the mycelium.

In all other experiments the osmotic potential of the enzyme solution was adjusted to $-\mathrm{I} 5.8 \mathrm{~atm}$, corresponding to $0.5 \mathrm{M}-\mathrm{MgSO}_{4}$ in $0.05 \mathrm{M}$-maleic acid- $\mathrm{NaOH}$ buffer ( $\mathrm{pH} 5^{.8}$ ).

\section{Effect of enzyme concentration}

Fig. 4 shows the effect of varying the concentration of the lytic enzyme preparation on the release and stability of protoplasts. Within the range tested, the rate of formation and the final number of protoplasts increased with increasing enzyme concentration. At all the enzyme concentrations used the protoplasts appeared stable, at least during to $\mathrm{h}$ of 


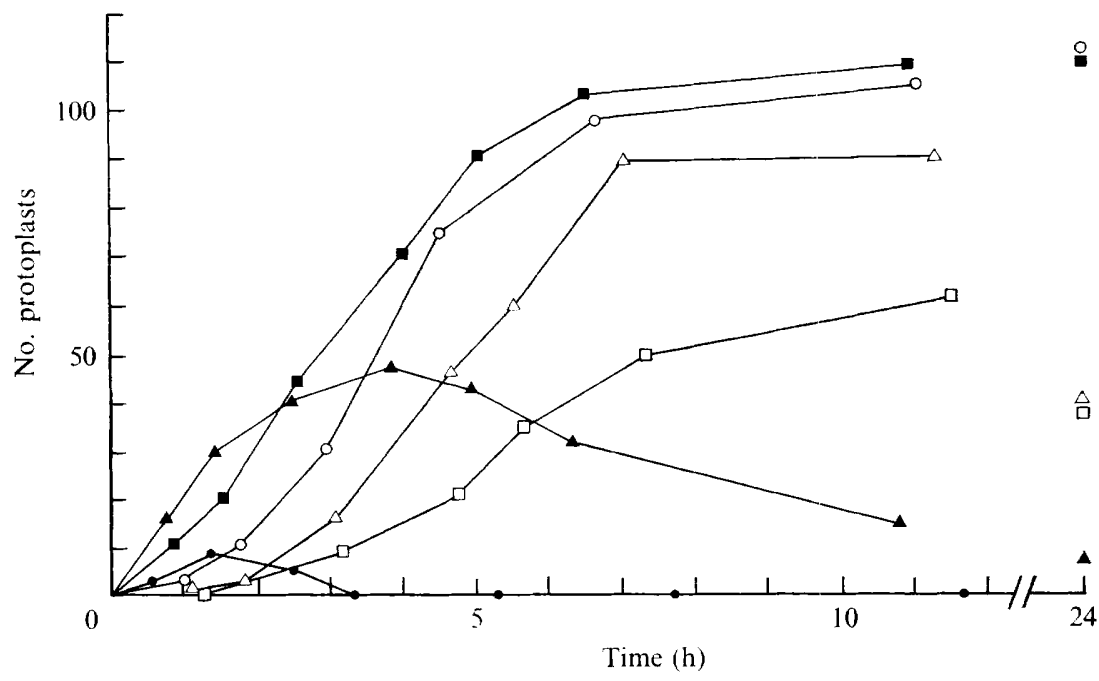

Fig. 3. Formation and stability of protoplasts in solutions of different osmotic potential produced by different concentration of $\mathrm{MgSO}_{4}$. $-1,-5.5 \mathrm{~atm}, \mathrm{O} \cdot \mathrm{I} \mathrm{M} ; \boldsymbol{\Lambda},-8 . \mathrm{I}$ atm, $0.2 \mathrm{M} ; \boldsymbol{\square},-\mathrm{I} 2.8 \mathrm{~atm}$, $0.4 \mathrm{M} ; 0,-17.8 \mathrm{~atm}, 0.6 \mathrm{M} ; \Delta,-23 . \mathrm{Iatm}, 0.8 \mathrm{M} ; \square,-29 . \mathrm{I} \mathrm{atm}, \mathrm{I} \cdot \mathrm{O} \mathrm{M}$. Other concentrations were: mycelium, $3.5 \mathrm{mg}$ dry wt $/ \mathrm{ml}$; Trichoderma enzymes, $1.0 \mathrm{mg}$ protein $/ \mathrm{ml}$; Na-maleate buffer, $0.05 \mathrm{M}$. Final pH 5.8 . Mycelial age 2 days. Protoplasts were counted in a haemocytometer.

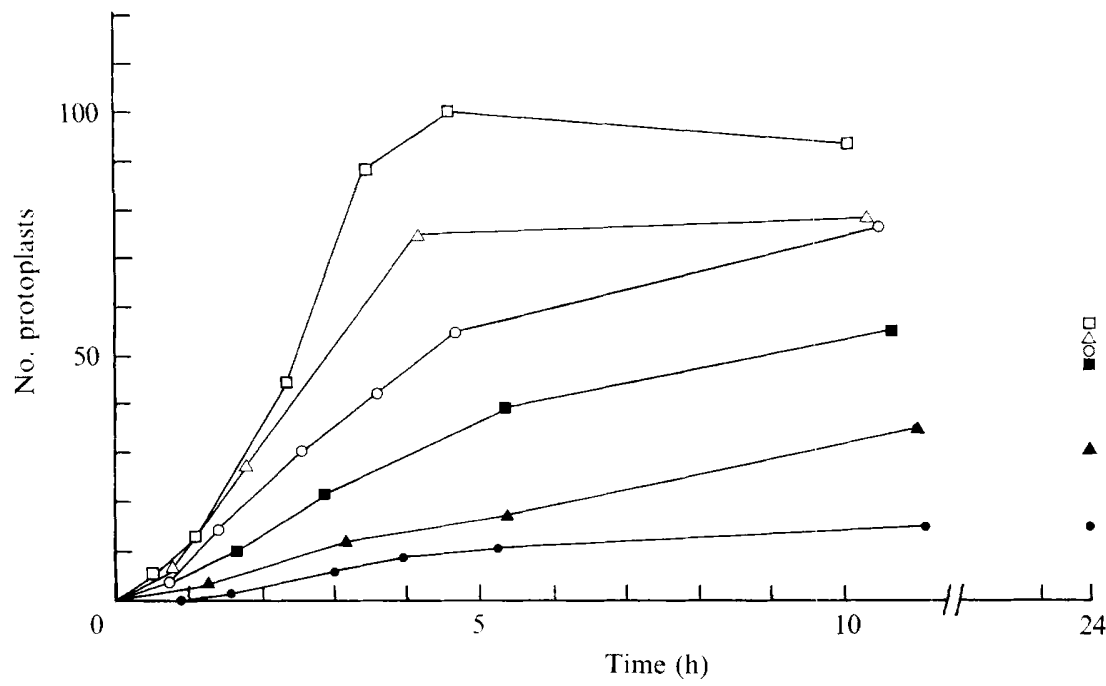

Fig. 4. Effect of the concentration of Trichoderma enzymes on the formation and stability of protoplasts. Concentrations of the Trichoderma enzyme preparation were (in $\mathrm{mg}$ protein $/ \mathrm{ml}$ ): $, 0,0.063$; $\Delta, 0.125 ; \boldsymbol{\square}, 0.5 ; 0,1.0 ; \Delta, 1.5 ; \square, 2.5$. Other concentrations were: mycelium, $6.5 \mathrm{mg}$ dry wt $/ \mathrm{ml}$; Na-maleate buffer, $0.05 \mathrm{M} ; \mathrm{MgSO}_{4}, 0.5 \mathrm{M}$. Final pH 5.8. Mycelial age 2 days. Protoplasts were counted in a haemocytometer. 


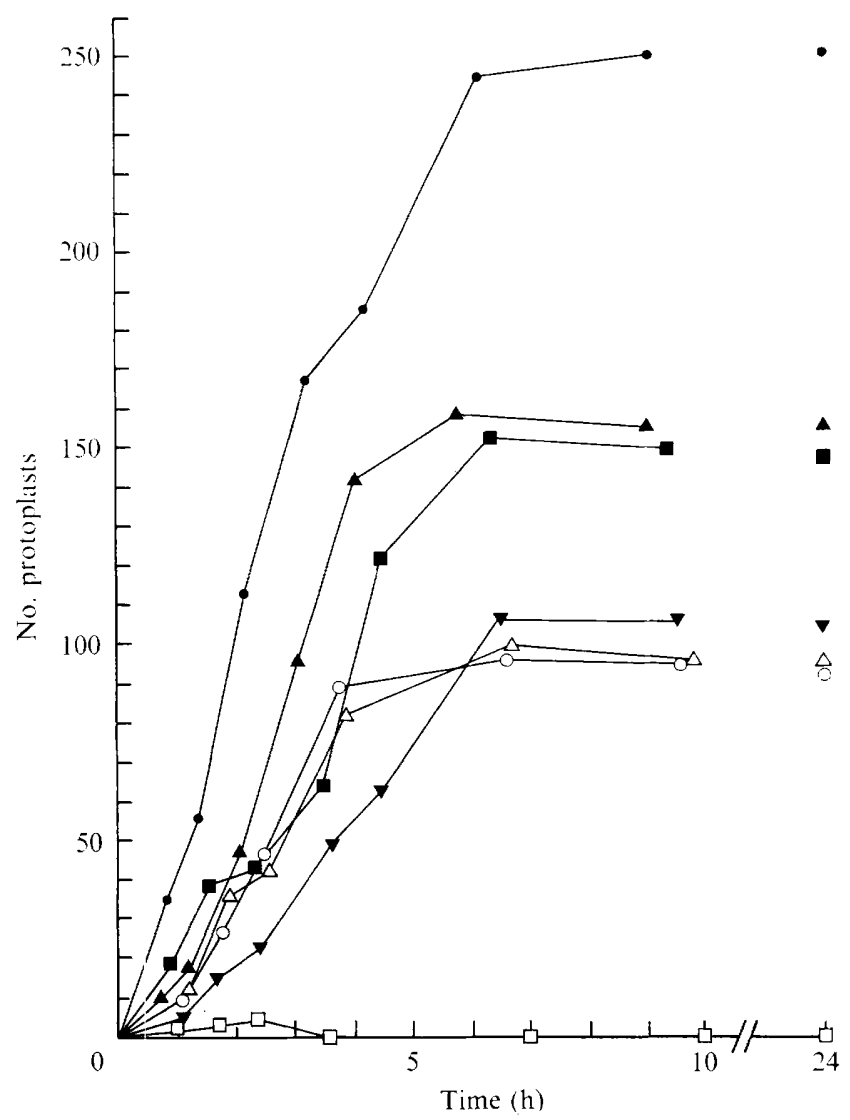

Fig. 5. Influence of different osmotic stabilizers at equal osmotic potential $(-15 \cdot 8 \pm 0.2 \mathrm{~atm})$ on the formation and stability of protoplasts. Osmotic stabilizers and their concentrations were: $\mathbf{K C l}$, $0.3 \mathrm{M} ; \boldsymbol{\Delta}, \mathrm{MgSO}_{4}, 0.5 \mathrm{M} ; \boldsymbol{\square}, \mathrm{NaCl}, 0.3 \mathrm{M} ; \boldsymbol{\nabla}, \mathrm{D}(+)$ sucrose, $0.5 \mathrm{M} ; \triangle, \mathrm{D}(-)$ mannitol, $0.5 \mathrm{M}$; $\mathrm{O}, \mathrm{D}(-)$ sorbitol, $0.5 \mathrm{M} ;[], \mathrm{NaNO}_{3}, 0.3 \mathrm{M}$. Other concentrations were: mycelium, $3 . \mathrm{I} \mathrm{mg}$ dry wt/ $\mathrm{ml}$; Trichoderma enzymes, I $\mathrm{mg}$ protein $/ \mathrm{ml}$; Na-maleate buffer, $0.05 \mathrm{M}$. Final pH 5.8. Mycelial age 2 days. Protoplasts were counted in a haemocytometer.

incubation. Counts after $24 \mathrm{~h}$ revealed a decrease in the number of protoplasts, especially at the higher enzyme concentrations.

\section{Effect of various osmotic stabilizers}

Various compounds were added to attain an osmotic potential of -15.8 atm and tested for their ability to support protoplast release and stability (Fig. 5). $\mathrm{NaNO}_{3}$ appeared to have an adverse effect on the living cytoplasm. Only during the first hours of incubation were a few protoplasts released, which, however, soon disintegrated. Incubation with $\mathrm{NaCl}$ or $\mathrm{MgSO}_{4}$ gave final numbers which were about $50 \%$ higher than those obtained with the organic stabilizers. By using $\mathrm{KCl}$ the largest number of protoplasts were released. Many of these protoplasts, however, were relatively small.

\section{Morphological observations}

The protoplasts began to emerge after Io min of incubation. They originated through pores which at first were mainly located at the tips of hyphae but later they also appeared in 
older hyphal compartments. Occasionally one single large protoplast, representing the whole content of the apical cell, was released but generally the cytoplasm was repeatedly constricted during the extrusion. This resulted in a cluster of separate protoplasts between which cytoplasmic connexions were occasionally observed (Fig. 6).

When $\mathrm{MgSO}_{4}$ was used as an osmotic stabilizer, the mycelium completely fragmented and protoplasts were then also released in large numbers from the open ends of older hyphae. Another phenomenon specific to the use of $\mathrm{MgSO}_{4}$ was a process of vacuolization, and swelling of vacuoles. After about 3 h of incubation large vacuoles could be seen in many of the protoplasts as well as in the cytoplasm still present in the hyphae (Fig. 6). The contents of the cell were discontinuously displaced towards the pore during protoplast formation (Fig. 7). During the extrusion of cytoplasm a passing vacuole frequently caused a widening of the pore or complete rupture of the hyphal tip, giving rise to a wide aperture through which the release of protoplasts was facilitated (Fig. 6).

The released protoplasts were usually spherical. Occasionally they bulged locally because of the presence of large vacuoles (Fig. 6). The size of the protoplasts immediately after liberation ranged from 2 to Io $\mu \mathrm{m}$. Sometimes spheres were released which looked like isolated vacuoles.

The relative density of the protoplasts varied, depending on the osmotic stabilizer used. In sorbitol, mannitol, $\mathrm{NaCl}$ and $\mathrm{KCl}$ the protoplasts sedimented by gravity. In sucrose their density was similar to that of the solution and they remained suspended. The behaviour of the protoplasts in $\mathrm{MgSO}_{4}$ was more complicated. As the swelling of the vacuoles proceeded two classes of protoplasts arose. One class consisted of floating protoplasts all of which contained one very large vacuole which displaced the cytoplasm to one side. In the cytoplasm some highly refractile bodies were often observed. The other class consisted of relatively small and dense protoplasts without a large vacuole and without these refractile bodies. These protoplasts sedimented by gravity.

The protoplasts were sensitive to osmotic shock. When placed in distilled water they swelled slightly and burst suddenly. Sometimes one or more optically empty vesicles, apparently vacuoles, remained in sight for some time. When placed in hypertonic solutions they shrank quickly. At the same time one or more long cytoplasmic threads arose which remained connected to the shrunken protoplasts. Often these threads bore one or more swellings probably due to enclosed bodies. When these shrunken protoplasts were subsequently placed in distilled water they swelled and burst.

In the presence of the osmotically stabilized enzyme solution, protoplasts could be stable for at least I week. Under these conditions they were not able to generate a new wall. During storage, protoplasts in $\mathrm{MgSO}_{4}$ solutions showed an increase in volume and some of them could reach a diameter of more than $30 \mu \mathrm{m}$. Besides one enormous vacuole, they contained many other denser vesicles, often the size of the original protoplast.

\section{DISCUSSION}

Hasegawa \& Nordin (I969) reported the presence of an inducible $\alpha$-I,3-glucanase in the culture filtrate of Trichoderma viride. An important difference between the lytic enzyme system from $T$. viride grown on walls of Schizophyllum commune and commercially available snail digestive juices is the ability of the former to attack S-glucan, the $\alpha$-I,3-linked glucan in the wall of $S$. commune (cf. Niederpruem \& Wessels, 1969). The inability of snail digestive juice to degrade $\alpha-I, 3$-glucan is in accordance with the results of Kanetsuna, Carbonell Moreno \& Rodriguez (I969). The presence of S-glucanase is correlated with the ability of 

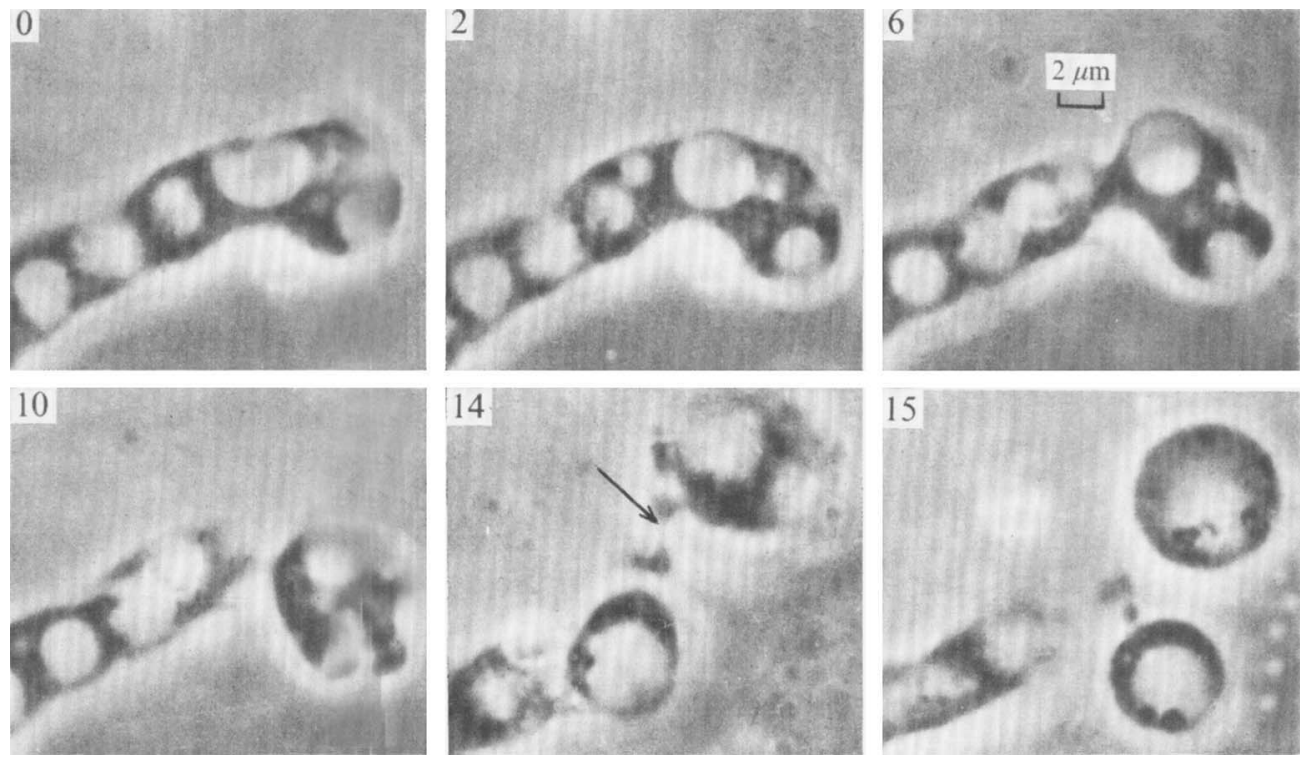

Fig. 6. Sequential release of two protoplasts of Schizophyllum commune from a ruptured hypha. A transient connexion between the two protoplasts is arrowed. Large vacuoles and bulging of the hypha can be seen. Photographs were taken $2.5 \mathrm{~h}$ after addition of the Trichoderma enzymes in the presence of $0.5 \mathrm{M}-\mathrm{MgSO}_{4}$. Observation times are indicated in minutes.
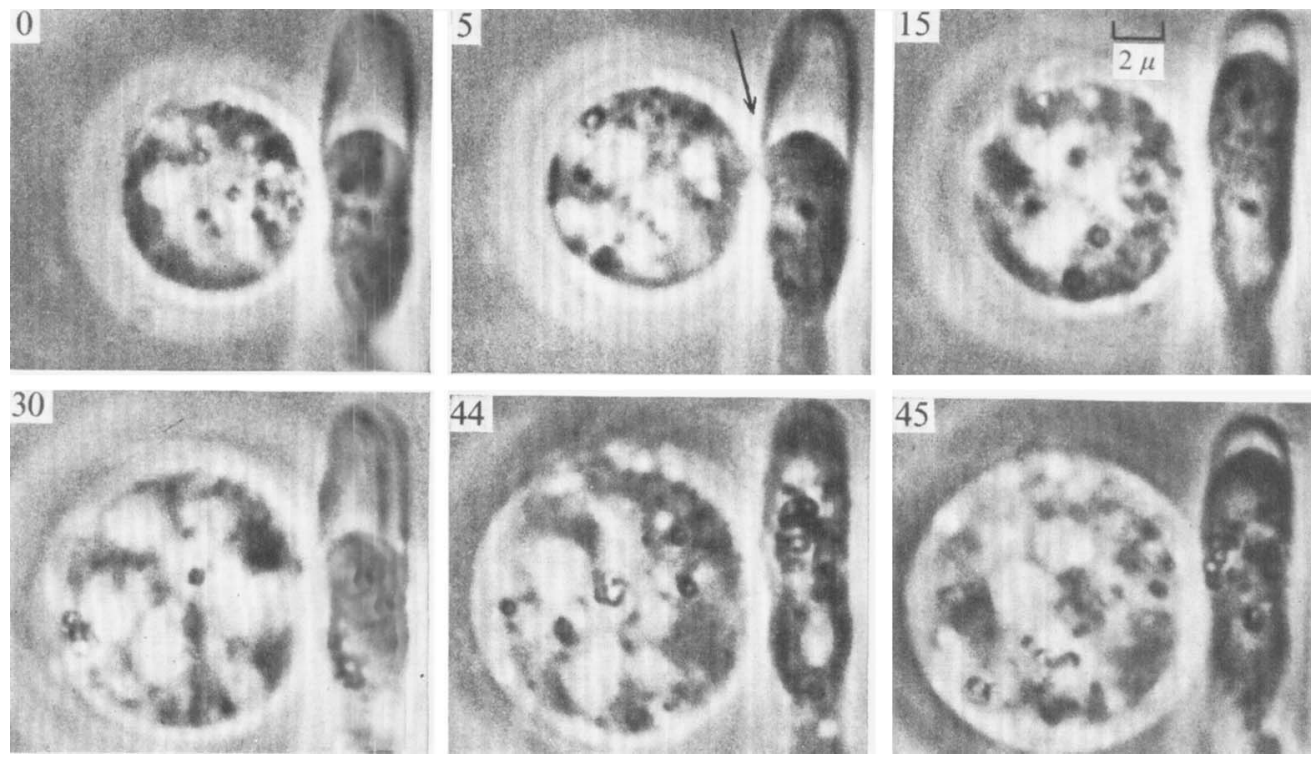

Fig. 7. The emergence of a protoplast of Schizophyllum commune through a pore in the hyphal wall about $8 \mu \mathrm{m}$ under the apex. The arrow indicates the connexion between the protoplast and the protoplasm still inside the hypha. As the protoplast is extruded the remaining protoplasm shows an irregular pulsating movement. Photographs were taken $\mathrm{I} \mathrm{h}$ after addition of the Trichoderma enzymes in the presence of $0.5 \mathrm{M}-\mathrm{MgSO}_{4}$. Observation times are indicated in minutes. 
the $T$. viride enzyme system to liberate protoplasts from the hyphae of $S$. commune. This suggests that in this organism degradation of S-glucan is necessary for the release of protoplasts. On the other hand snail enzymes are very effective in releasing protoplasts from many yeasts and filamentous fungi (Villanueva \& Garcia Acha, 1971). Snail enzymes have also been used to release protoplasts from Aspergillus niger (Musílková \& Fencl, I968) and Schizosaccharomyces pombe (Rost, 1969) both of which have been shown to contain an $\alpha-1,3$-glucan in their walls (Johnston, 1965; Bacon, Jones, Farmer \& Webley, 1968). This suggests that the occurrence of S-glucan in the wall does not always necessitate the action of an S-glucanase in order to effect the release of protoplasts.

The results have shown that the protoplasmic spheres are extruded through ruptures in the wall and apparently lack a wall. Most important, they are osmotically sensitive. According to Villanueva \& Garcia Acha (I97I) these structures are therefore considered as protoplasts.

One critical factor determining the number of protoplasts is the age of the culture. In accordance with general experience it is necessary to use young growing mycelium as a starting material. Whether this relates to differences in the structure of the hyphal wall or to other age-dependent conditions of the mycelium is not clear.

Protoplast release is optimal at $\mathrm{pH} 5 \cdot 8$. This is near the value used in most other systems, except in the case of the basidiomycete Polystictus versicolor (Strunk, I969) where a pH around 7 was used.

Of several compounds tested at a final osmotic potential of $-\mathrm{I}_{5} .8 \mathrm{~atm}, \mathrm{MgSO}_{4}$ and $\mathrm{KCl}$ proved to be the most effective. The use of these salts instead of organic compounds also has the advantage of preventing bacterial growth during incubation (Gascón \& Villanueva, I965). $\mathrm{MgSO}_{4}$ is preferred because the conversion of cytoplasmic contents into protoplasts is most complete with this salt. Moreover, in $\mathrm{MgSO}_{4}$ most of the liberated protoplasts developed large vacuoles and floated. This enables a convenient separation of these protoplasts from the hyphal fragments by low-speed centrifugation. $\mathrm{MgSO}_{4}$ has also been used by other workers (Sietsma, Eveleigh, Haskins \& Spencer, 1967; Sietsma \& Wouters, 1971) but at about twice the concentration shown to be optimal for Schizophyllum commune.

The availability of a reproducible and effective method for obtaining protoplasts from Schizophyllum commune may be of great advantage for further investigations with this organism. For instance, preliminary experiments have shown that at least $10 \%$ of the protoplasts from $S$. commune can regenerate a wall and eventually develop into normal hyphae under suitable conditions.

We acknowledge the assistance of Mrs A. M. Cortel-Breeman in part of the experiments.

\section{REFERENCES}

Bacon, J. S. D., Jones, D., Farmer, V. C. \& Webley, D. M. (1968). The occurrence of $\alpha(\mathrm{I}-3)$ glucan in Cryptococcus, Schizosaccharomyces and Polyporus species and its hydrolysis by a Streptomyces culture filtrate lysing cell walls of Cryptococcus. Biochimica et biophysica acta 158, 313-315.

Bartnicki-Garcia, S. \& Lippman, E. (1966). Liberation of protoplasts from the mycelium of Phytophthora. Journal of General Microbiology 42, 4I I-4I 6.

Dygerts, S., LI, L. H., Florida, D. \& Thoma, J. A. (I965). Determination of reducing sugar with improved precision. Analytical Biochemistry 13, 367-374.

Fairbairn, N. J. (1953). A modified anthrone reagent. Chemistry \& Industry 72, 86.

Gascón, S. \& Villanueva, J. R. (I965). Magnesium sulphate as stabilizer during liberation of yeast and mould protoplasts. Nature, London 205, 822-823.

Hasegawa, S. \& Nordin, J. H. (1969). Enzymes that hydrolyse fungal cell wall polysaccharides. I. Purification and properties of an endo- $\alpha$-D-(I-3)-glucanase from Trichoderma viride. Journal of Biological Chemistry 244, 5460-5470. 
JoHnston, I. R. (1965). The composition of the cell wall of Aspergillus niger. Biochemical Journal 96, 65 I-658.

Kanetsuna, F., Carbonell, L. M., Moreno, R. E. \& Rodriguez, J. (1969). Cell wall composition of the yeast and mycelial forms of Paracoccidioides brasiliensis. Journal of Bacteriology 97, 1036-I04I .

Lowry, O. H., Rosebrough, N. J., Farr, A. L. \& Randall, R. J. (I95I). Protein measurement with the Folin phenol reagent. Journal of Biological Chemistry I93, 265-275.

Mandels, M., Parrish, F. W. \& Reese, E. T. (1962). Sophorose as an inducer of cellulase in Trichoderma viride. Journal of Bacteriology 83, 400-408.

Musílkoví, M. \& FenCL, Z. (5968). Some factors affecting the formation of protoplasts in Aspergillus niger. Folia microbiologica $\mathbf{1 3}, 235-239$.

Niederpruem, D. J. \& Wessels, J. G. H. (1969). Cytodifferentiation and morphogenesis in Schizophyllum commune. Bacteriological Reviews 33, 505-535.

Reissig, J. L., Strominger, J. L. \& Leloir, L. F. (I955). A modified colorimetric method for the estimation of $N$-acetylaminosugars. Journal of Biological Chemistry 217, 959-966.

Rost, K. (1969). Gewinnung und Eigenschaften von Protoplasten aus Schizosaccharomyces pombe. Zeitschrift für allgemeine Mikrobiologie 9, 289-295.

Siftsma, J. H., Eveleigh, D. E., Haskins, R. H. \& Spencer, J. F. T. (1967). 'Protoplasts' from Pythium sp. PRL 2142. Canadian Journal of Microbiology 13, I70 I-I 704.

Sietsma, J. H. \& Wouters, J. T. M. (r97I). Cell wall composition and 'protoplast' formation of Geotrichum candidum. Archiv für Mikrobiologie 79, 263-273.

Skujins, J. J., Potgieter, H. J. \& Alexander, M. (1965). Dissolution of fungal cell walls by a Streptomycete chitinase and $\alpha$-(I-3)glucanase. Archives of Biochemistry and Biophysics 111, 358-364.

StrunK, C. (1969). Licht- und elektronenmikroskopische Untersuchungen an jungen Protoplasten von Polystictus versicolor. Zeitschrift für Allgemeine Mikrobiologie 9, 49-6o.

Strunk, C. (1970). Protoplasts of moulds - the present state of knowledge. In Proceedings International Symposium of Yeast protoplasts (Brno), pp. I07-1 19. Edited by O. Nečas and A. Svoboda. Brno: University J. E. Purkyně.

Villanueva, J. R. \& Garcia Acha, I. (I97I). Production and use of fungal protoplasts. In Methods in Microbiology, vol. 4, pp. 655-718. Edited by C. Booth. New York: Academic Press.

WALSETH, C. S. (1963). In Methods in Carbohydrate Chemistry, vol. III, pp. IOO-IOI. Edited by R. L. Whistler. New York: Academic Press.

Wessels, J. G. H. (1965). Morphogenesis and biochemical processes in Schizophyllum commune Fr. Wentia I3, I-I I 3 .

Wessels, J. G. H. (1971). Cell wall metabolism and morphogenesis in Schizophyllum. Proceedings Xth International Congress of Microbiology (Mexico), pp. I41-I46. 